\title{
Assessment of medical waste management in the main hospitals in Yemen
}

A.A. Al-Emad ${ }^{1}$

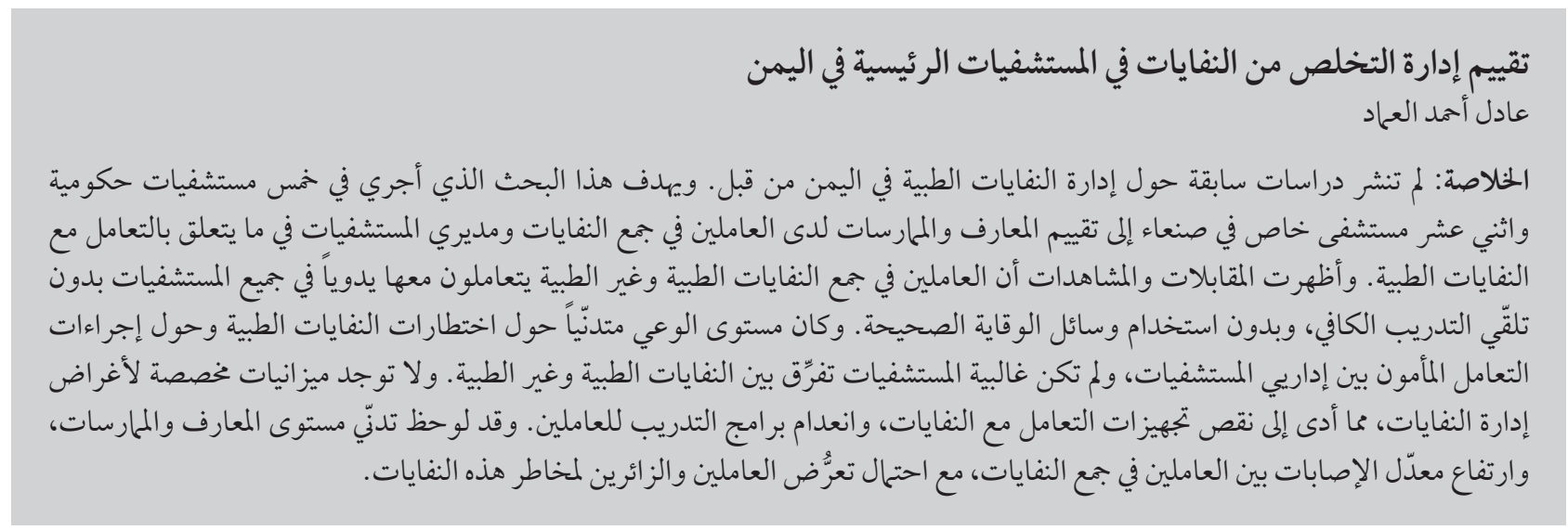

ABSTRACT No previous studies about the management of medical waste have been published in Yemen. This research in 5 government and 12 private hospitals in Sana'a aimed to evaluate waste-workers' and hospital administrators' knowledge and practices regarding medical waste handling. Interviews and observations showed that the waste-workers were collecting medical and nonmedical wastes together manually in all hospitals without receiving adequate training and without using proper protection equipment. There was poor awareness about medical waste risks and safe handling procedures among hospital administrators, and most hospitals did not differentiate between domestic and medical waste disposal. Budgets were not allocated for waste management purposes, which led to shortages in waste handling equipment and an absence of training programmes for staff. Poor knowledge and practices and a high rate of injuries among waste-workers were noted, together with a risk of exposure of staff and visitors to hazardous waste.

\section{Évaluation de la gestion des déchets médicaux dans les principaux hôpitaux du Yémen}

RÉSUMÉ Aucune étude de la gestion des déchets médicaux n'a été publiée précédemment au Yémen. La présente recherche conduite dans cinq hôpitaux publics et douze hôpitaux privés de Sanaa visait à évaluer les connaissances des agents de collecte des déchets et des administrateurs des hôpitaux concernant la manipulation des déchets médicaux et leurs pratiques en la matière. Des entretiens et des observations ont permis de révéler que les agents collectaient les déchets médicaux et non médicaux à la main dans tous les hôpitaux sans avoir reçu de formation adéquate ni utiliser les outils de protection adaptés. Les connaissances en termes de risques représentés par les déchets médicaux et de procédures de manipulation étaient faibles parmi les administrateurs des hôpitaux, et la plupart des hôpitaux ne séparaient pas les déchets ménagers des déchets médicaux. L'absence d'allocation de budgets à la gestion des déchets a conduit à l'insuffisance des équipements de manutention des déchets et à l'absence de programmes de formation pour le personnel. Des connaissances faibles, des mauvaises pratiques ainsi qu'un taux élevé de blessures chez les agents de collecte ont été observés, mais aussi un risque d'exposition du personnel et des visiteurs aux déchets dangereux.

${ }^{7}$ Department of Community Medicine, Faculty of Medicine and Health Sciences, University of Sana'a, Sana'a, Yemen (Correspondence to A.A. AlEmad: Dr.Adel.Alemad@gmail.com).

Received: 09/05/10; accepted: 04/04/11 


\section{Introduction}

Over the last few decades, progress in medical science and technology and expansion in the number of health institutions worldwide has been accompanied by increasing quantities of potentially hazardous medical waste $[1,2]$. The risks include occupational exposure of health workers and wastehandlers and environmental exposure of the public caused directly by illegal or careless management and disposal practices or indirectly through emissions and ash handling from medical waste incinerators [3]. In 2002 the World Health Organization (WHO) reported that underdeveloped countries suffer the greatest burden of risk from medical waste due to the high costs of proper disposal procedures. The spread of bloodborne pathogens in health care waste [4] motivated the WHO in 2004 to call for the development of national policies, guidance and plans for health care waste management [5].

Although a number of studies have been made of medical waste handling [6-8], research in the Arab region is limited. A study in Palestine of medical waste management in hospitals found that there was insufficient separation between hazardous and non-hazardous wastes, an absence of necessary rules and regulations for collection, transport and treatment of waste and a lack of training and protective equipment [9]. Another study in Palestine comparing the management of medical waste in primary health care centres and private clinics showed that most workers in the public sector did not follow correct methods of handling medical waste [10]. In Yemen, no published studies can been found and no protocols exist for the management of medical waste, although a report about the cleaning of medical facility waste in the capital was issued in 2006 [11].

The present study aimed to evaluate the management of medical waste in the largest hospitals in Yemen. The specific objectives were to: identify the types of medical waste produced, identify and evaluate collection procedures, assess waste-workers' knowledge and practices, identify and evaluate disposal and clearance procedures and assess hospital administrators' knowledge regarding medical waste.

\section{Methods}

\section{Setting and sample}

This descriptive study was carried out in Sana'a, the capital of Yemen, which has the majority of large hospitals in Yemen. The study sample was the departments and waste-workers in hospitals larger than 50 beds. The study included 5 government hospitals (Al-Thowra, Kuwait, Republican, Al-Sabieen, Police) and 12 private hospitals (Saudi-German, Science University, Azaal, Yemeni-German, Modern-German, Ibn Cynaa, AlAhly, Al-Motawakil, Al-Om, Al-Horabi, Tiabah, Al-Amal). The literature was reviewed, the research framework was designed, the questionnaire was prepared and the fieldwork was completed from August 2007 to December 2008. The fieldwork was achieved after notices from the dean of the faculty of medicine in the University of Sana' a to the general managers of the selected hospitals. Permission was obtained from the hospitals prior to conducting the interviews with workers.

\section{Data collection}

A number of instruments were used for data collection as follows:

\section{Knowledge and practices of hospital administrators}

This was assessed using a special form covering their awareness about the importance of medical waste and their management role. Forms were filled through personal interviews with the official responsible for waste at each hospital. The form contained 13 items and was administered to the 17 hospital administrators, 1 at each hospital.

\section{Knowledge and practices of waste- workers}

This was assessed using a special form which included knowledge about the risks of and proper disposal procedures for medical waste and the collection practices followed. The form contained 19 items in 5 categories: nature of wastes; collection, separation and packaging; transportation and disposal; risks; and administrative issues. Forms were filled through personal interviews with 211 workers (87 workers at government hospitals and 124 workers at private hospitals). At least half of the employees in each hospital were included.

The number of active workers in all the hospitals was estimated to be about 300 cleaning workers, taking into account possible inaccuracies in the reported numbers of workers in most hospitals. Translators were used as many of the waste-workers were from countries located in the Horn of Africa (Somalia, Ethiopia) and lacked mastery of Arabic or English languages.

\section{Practices of workers in handling med- ical waste}

Actual practices were assessed using a form which was designed according to WHO criteria for collection of medical waste [12]. The form contained 25 items in 5 categories similar to those of the form for assessing the knowledge and practices of waste workers. All waste observations were made through direct site inspections to check the agreement between the interview data and the actual practices.

\section{Results}

\section{Knowledge and practices of hospital administrators}

Table 1 illustrates the self-reported knowledge and practices of hospital administrators in relation to medical waste. Only $20.0 \%$ of administrators in government hospitals confirmed the importance of having specialized wasteworkers available, while none of those in 


\begin{tabular}{|c|c|c|}
\hline \multirow[t]{2}{*}{ Item } & $\begin{array}{l}\text { Government hospitals } \\
\qquad(n=5)\end{array}$ & $\begin{array}{l}\text { Private hospitals } \\
\qquad(n=12)\end{array}$ \\
\hline & $\%$ & $\%$ \\
\hline Knows importance of availability of specialized waste-workers & 20.0 & 0.0 \\
\hline Provide personal protection tools for workers & 20.0 & 33.2 \\
\hline Monitor usage of personal protection tools & 80.0 & 91.7 \\
\hline Train workers in dealing with medical waste & 80.0 & 74.7 \\
\hline Medical waste user manual available & 0.0 & 8.3 \\
\hline $\begin{array}{l}\text { Raise workers awareness about knowing and dealing with medical } \\
\text { waste }\end{array}$ & 100.0 & 75.1 \\
\hline Workers supervised during waste collection & 20.0 & 66.8 \\
\hline Medical waste budget available & 0.0 & 0.0 \\
\hline Adequate waste allocation within hospital cleaning budget & 100.0 & 83.0 \\
\hline $\begin{array}{l}\text { Department responsible for waste available within hospital } \\
\text { management }\end{array}$ & 0.0 & 66.8 \\
\hline Adequate number of workers collecting waste & 60.0 & 83.0 \\
\hline Collect waste 3 or more times per day & 100.0 & 41.5 \\
\hline
\end{tabular}

$n=$ number of hospitals.

private hospitals did so. Personal safety tools were provided to waste-workers by $20.0 \%$ of government hospitals and $33.2 \%$ of private hospitals, and their use was monitored in $80.0 \%$ and $91.7 \%$ of government and private hospitals respectively. None of the government hospitals, and very few private hospitals, had waste user manuals. All government hospitals claimed to be raising awareness of workers about dealing with medical waste, while three-quarters of the private hospitals reported this. Only one-fifth of the government hospitals and two-thirds of the private hospitals supervised their workers during waste collection.

None of the hospitals had a dedicated budget for waste handling, but many hospitals had an allocation for waste management within the hospital cleaning budget. Two-thirds of the private hospitals had a department responsible for waste collection, whereas none of the government hospitals did.

All government hospitals reported that they collected waste 3 times or more per day while less than half of the private hospitals were doing so (Table 1).

\section{Waste-workers' knowledge of dealing with medical waste}

Table 2 shows the waste-workers' knowledge about dealing with medical waste. It was found that $11.5 \%$ and $45.9 \%$ of workers in government and private hospitals respectively were able to identify the types of medical waste they were collecting. Few of the government hospitals workers (19.5\%) and more than half of the private hospitals workers $(61.3 \%)$ considered it necessary to sort medical waste. Only $11.5 \%$ of the workers in government hospitals and $44.4 \%$ of the workers in private hospitals could understand the reasons behind sorting medical waste. Consequently none of the government hospitals workers and only $25.0 \%$ of the private hospitals workers knew the adequate quantities for packing medical waste.

Concerning risks that workers could be exposed to during handling medical waste, $68.9 \%$ of government and $70.9 \%$ of private hospitals workers seemed to be aware of these. Regarding knowledge of adequate disposal procedures of liquid waste, expired blood units, human tissue remains and expired medicines, the percentages were $12.6 \%, 7.0 \%, 4.5 \%$ and $4.0 \%$ respectively for government hospitals workers, and $37.1 \%, 8.8 \%$, $6.5 \%$ and $0.0 \%$ respectively for private hospitals workers. The percentages of workers who believed that throwing expired blood units, human tissue remains and expired medicines into the normal domestic rubbish collection was an adequate disposal procedure were $69.0 \%, 43.7 \%$ and $39.5 \%$ respectively for government hospitals, whereas for private hospitals these were $65.3 \%, 13.7 \%$ and $65.5 \%$ respectively (Table 2 ).

\section{Actual practices of workers in handling medical waste}

Table 3 presents the results of the assessment of the actual practices of workers in handling medical waste. None of the government hospitals were sorting their medical waste and $20.0 \%$ of them were only separating sharps from blunt instruments, whereas $16.7 \%$ of the private hospitals were sorting waste and half of them were separating sharps from blunt ones. None of the government hospitals and $8.3 \%$ of the private hospitals had workers filling wastes sacks to two-thirds or less. 


\begin{tabular}{lcc}
\hline Table 2 Waste-workers' knowledge about dealing with medical waste in government and private hospitals \\
\hline Item & $\begin{array}{c}\text { Government } \\
\text { hospitals } \\
(\boldsymbol{n}=\mathbf{8 7})\end{array}$ & $\begin{array}{c}\text { Private } \\
\text { hospitals } \\
(\boldsymbol{n}=\mathbf{1 2 4})\end{array}$ \\
$\begin{array}{l}\text { \% } \\
\text { Able to identify nature of medical waste }\end{array}$ & 11.5 & 45.9 \\
Identifies need to sort medical waste during collection & 19.5 & 61.3 \\
Know reasons behind sorting medical wastes & 11.5 & 44.4 \\
Know adequate quantities for packing medical waste & 0.0 & 25.0 \\
Aware of risks in dealing with medical wastes & 68.9 & 70.9 \\
Knows adequate disposal procedures of liquid waste & 12.6 & 37.1 \\
Knows adequate disposal procedures of expired blood units and by-products waste & 7.0 & 8.8 \\
Knows adequate disposal procedures of human tissue remains & 4.5 & 6.5 \\
Knows adequate disposal procedures of expired medicines & 4.0 & 0.0 \\
Believes throwing blood waste in domestic waste is an adequate disposal procedure & 69.0 & 65.3 \\
Believes throwing of human tissue remains in domestic waste is an adequate disposal & & 13.7 \\
procedure & 43.7 & 65.5 \\
Believes throwing expired medicines in domestic waste is an adequate disposal procedure & 39.5 & \\
\hline
\end{tabular}

$n=$ number of waste workers interviewed.

For government hospitals, $60.0 \%$ were using trolleys to move medical waste, and none of them were cleaning trolleys after each collection process. For private hospitals, $25.0 \%$ were using trolleys and $8.3 \%$ of them were cleaning trolleys after each collection.

Workers in $20.0 \%$ of the government hospitals and $33.3 \%$ of the private hospitals were using personal protection tools. Those who were not using protection claimed that the tools were not provided by their supervisors.

None of the government hospitals were using the waste bags only once, and only $8.3 \%$ of the private hospitals were using them once. Workers were collecting liquid waste, blood waste and human tissue remains in separate bags in $8.3 \%, 16.7 \%$ and $25.0 \%$ respectively of private hospitals, while none of the government hospitals were doing any of these. On the other hand, for hospitals where workers were using the same bags for collecting liquid waste, blood waste, human tissue remains and expired medicines with other wastes, the percentages for private hospitals were $50.0 \%, 83.3 \%$, $75.0 \%$ and $41.7 \%$ respectively, while for government hospitals these were $20.0 \%$, $100 \%, 100 \%$ and $100 \%$ respectively.
Workers were disposing liquid waste directly into the sewage system without any processing (dilution and/ or sterilization) in $20.0 \%$ and $50.0 \%$ of government and private hospitals respectively, and were disposing of liquid wastes into the sewage after processing (dilution and/or sterilization) in 60.0\% and $25.0 \%$ of these hospitals respectively. None of the government hospitals were sending expired medicines back to importers, while $58.3 \%$ of the private hospitals were doing so. None of the government or private hospitals had a furnace for destroying medical waste.

In $80.0 \%$ of the government hospitals and $75.0 \%$ of the private hospitals, visitors were exposed to medical waste in one way or another. All government hospitals and $83.3 \%$ of the private hospitals were gathering medical waste in open areas within the hospitals for temporary storage before it was transferred to final dumping destinations outside the hospital. None of government hospitals and only $8.3 \%$ of private hospitals had standard stores for temporary storage of medical waste. All government hospitals and $83.3 \%$ of private hospitals were depending on the city cleaning authorities for transporting and disposing of medical wastes outside hospitals. None of the government hospitals and only $8.3 \%$ of private hospitals were moving and disposing of medical wastes outside hospitals using their own vehicles (Table 3).

\section{Workers' injuries caused by medical wastes}

Table 4 gives an indication of workers' injuries caused by medical waste in government hospitals and private hospitals and administration responses. The rate of injuries during the previous 12 months in government and private hospitals were $28.7 \%$ and $27.4 \%$, respectively according to workers' reports. Administrators ignored $16.1 \%$ of reported injuries in government hospitals and $7.3 \%$ in private ones.

\section{Discussion}

\section{Knowledge and practices of hospital administrators}

It was concerning to realize that administrators of the majority of government hospitals and private hospitals in this study in Sana'a did not see the necessity of having specialized waste-workers within the hospital. This indicates 


\begin{tabular}{|c|c|c|}
\hline Item & $\begin{array}{l}\text { Government hospitals } \\
\qquad(n=5)\end{array}$ & $\begin{array}{l}\text { Private hospitals } \\
\qquad(n=12)\end{array}$ \\
\hline Workers sort medical waste during collection & 0.0 & 16.7 \\
\hline Workers separate sharp waste is from blunt waste & 20.0 & 50.0 \\
\hline Workers fill sacks with medical waste to two-thirds or less & 0.0 & 8.3 \\
\hline Workers move medical waste using trolleys & 60.0 & 25.0 \\
\hline Workers clean waste trolleys directly after each collection & 0.0 & 8.3 \\
\hline Workers use personal protection tools & 20.0 & 33.3 \\
\hline Workers are using special plastic bags once for collecting medical waste & 0.0 & 8.3 \\
\hline Workers collect liquid waste in bags that prevent leakage & 0.0 & 8.3 \\
\hline Workers collect blood waste in separate bags that prevent leakage & 0.0 & 16.7 \\
\hline $\begin{array}{l}\text { Workers collect human tissue remains in separate bags that prevent } \\
\text { leakage }\end{array}$ & 0.0 & 25.0 \\
\hline Workers collect liquid wastes together with other wastes & 20.0 & 50.0 \\
\hline Workers collect blood waste together with other waste in ordinary bags & 100.0 & 83.3 \\
\hline $\begin{array}{l}\text { Workers collect human tissue remains together with other wastes in } \\
\text { ordinary bags }\end{array}$ & 100.0 & 75.0 \\
\hline Workers collect expired medicines together with other wastes & 100.0 & 41.7 \\
\hline $\begin{array}{l}\text { Workers dispose of liquid waste directly into sewage system without any } \\
\text { processing (dilution and/or sterilization) }\end{array}$ & 20.0 & 50.0 \\
\hline Workers dispose of liquid waste into sewage system after processing & 60.0 & 25.0 \\
\hline Hospital sends expired medicines back to the importer & 0.0 & 58.3 \\
\hline Hospital has furnaces for internal destruction of medical waste & 0.0 & 0.0 \\
\hline Hospital visitors are exposed to medical waste & 80.0 & 75.0 \\
\hline $\begin{array}{l}\text { Workers gather medical wastes in open areas within the hospital for } \\
\text { temporary storage before being transferred outside hospitals }\end{array}$ & 100.0 & 83.3 \\
\hline Hospital has standard stores for temporary storage of medical wastes & 0.0 & 8.3 \\
\hline $\begin{array}{l}\text { Hospital depends on city cleaning authorities in moving and disposing } \\
\text { medical wastes outside hospitals }\end{array}$ & 100.0 & 83.3 \\
\hline $\begin{array}{l}\text { Hospital moves and disposes of medical wastes outside hospital using } \\
\text { own vehicles }\end{array}$ & 0.0 & 8.3 \\
\hline
\end{tabular}

$n=$ number of hospitals.

insufficient awareness about the risks to public health and the environment that medical waste could cause or about the importance of its regular and proper collection and clearance. This is similar to what was founded in Palestinian hospitals and medical centres $[10,13]$.

Private hospital companies may be reluctant to invest or spend money to prevent or to control pollution levels that are causing potential damage to the environment. This may be because they do not wish to reduce their profit margins or due to lack of knowledge, information and awareness about the

\begin{tabular}{|c|c|c|c|c|}
\hline \multirow[t]{2}{*}{ Variable } & \multicolumn{2}{|c|}{$\begin{array}{l}\text { Government hospitals } \\
\qquad(n=87)\end{array}$} & \multicolumn{2}{|c|}{$\begin{array}{l}\text { Private hospitals } \\
\qquad(n=124)\end{array}$} \\
\hline & No. & $\%$ & No. & $\%$ \\
\hline Worker did not report injury & 6 & 6.9 & 5 & 4.0 \\
\hline Worker reported injury but ignored by administration & 14 & 16.1 & 9 & 7.3 \\
\hline Worker sought treatment at own expense & 3 & 3.4 & 11 & 8.9 \\
\hline Worker received checkup and treatment from administration & 2 & 2.3 & 9 & 7.3 \\
\hline Total & 25 & 28.7 & 34 & 27.4 \\
\hline
\end{tabular}

$n=$ number of waste workers interviewed. 
dangers of pollution and lack of understanding about the social and economic values of preserving a clean environment [14].

Most of the hospital administrators claimed that they provided all necessary personal safety tools to their wasteworkers, but on interviewing workers during the field survey it turned out that the availability of such tools was realized in only 5 out of the 17 hospitals surveyed and, even in these hospitals, the tools were not as complete as they should be. Moreover, although most administrators in government and private hospitals reported that they supervised the use of personal safety tools by their workers, actual field observations and workers' reports revealed that less than half of the hospitals exercised such supervision. Also, there were no penalties imposed on violations except in the case of 1 private hospital. Despite claiming that there was training for workers in dealing with medical waste, hospitals had no formal training programmes except at 1 private hospital. The main reason was due to lack of a dedicated budget for waste management and the lack of attention given to the issue of medical waste. Since only 1 private hospital had a user manual for collecting medical waste, this meant that each wasteworker had to improvise his/her own way of doing things, which maximized the risks that workers were exposed to. Even worse were the findings that out of the 14 hospitals which claimed to raise their workers' awareness about the risks of handling medical wastes, only 1 was actually doing so.

More than half of the study sample of hospitals depended on private cleaning companies for collecting waste. These same companies were the ones responsible of supervising waste-workers, thus making the process susceptible to weaknesses aggravated by lack of adequate monitoring performed by the targeted hospitals. Some cleaning companies tended to register more workers than actually deployed for cleaning. Hospitals can improve this situation by establishing their own waste departments and employing qualified personnel. In general, the establishment of standard operating procedures is regarded as an effective way to ensure the proper handling, storage and transportation of medical wastes [3]. Obviously this requires each hospital to have a budget for waste management. In fact, field observations revealed that the money spent on waste collection and disposal was only a small allocation under a general purpose cleaning budget for hospitals, and was far from sufficient to cover the expenses of handling waste. A similar result was found in Lebanon, where $93 \%$ of the hospitals had no budget for waste management or a budget that was judged to be insufficient [15].

To ensure continuity and clarity in these management practices, clear plans and policies for proper wastes management and disposal are needed. These need to be integrated into routine employee training, continuing education and hospital management evaluation processes. Governments could require waste management plans from all hospitals as a condition for licensing [16].

\section{Knowledge of waste-workers}

Workers lacked adequate training in safe handling of medical waste. Therefore they had little knowledge regarding identification of types of medical waste, the necessity of sorting waste and adequate quantities for packing waste. Our field surveys showed that ignorance about medical waste disposal was at an alarming level, as many of the workers believed that disposing of waste in the normal domestic waste collection was the best method. On the other hand, disposing of medical waste by incineration can create additional pollution problems, because incineration releases toxic materials into the surrounding environment and it is more expensive to clean up emissions after burning than to prevent pollution in the first place [17].

\section{Actual practices of waste- workers}

None of the hospitals had special workers for collecting medical waste since workers were responsible of collecting all types of waste in addition to all other cleaning tasks. Therefore, workers were not giving much care to the nature and types of waste they were collecting as all waste was collected into the same bags. This complicated the sorting processes, exposed transport workers to infection risks and caused leakage of liquid wastes and possible pollution. The United Nations Environmental Programme has established that only $10 \%$ of health care waste is considered to be "potentially infectious" [18]. The proportion can be further reduced to $1 \%-5 \%$ with proper segregation practised at source. Based on epidemiological and microbiological data, only 2 types of medical waste would require special handling and treatment: sharps and microbiological waste [19]. Only 2 out of the study hospitals were collecting different types of waste in separate bags, whereas the rest were collecting all types of waste together, and about half of them were separating only sharp items from the rest. One reason was the unavailability of bags other than those for regular waste, and these bags were overfilled, thus escalating the problem further. Only 3 study hospitals were using bags that complied with international standards for collecting medical waste. Unfortunately these bags were being reused in 1 of the 3 hospitals, exposing a focus on short-term cost over the long-term costs of clearing up pollution.

Another serious problem prevailing in hospitals was the improper internal transportation of medical wastes, as some hospitals were doing it manually while others were doing it by overloading trolleys. These practices were causing bags to drop and be torn, thus polluting the surroundings and possibly harming workers, patients and visitors. Such risks were increased by practices 
such as continuous use of waste trolleys without rinsing. In this regard, the situation was worse in government than private hospitals.

Another dangerous practice followed by some study hospitals was the disposal of liquid medical wastes directly into the city sewage system without sterilization or dilution. Concerning expired medicines the situation was even worse, since more than half of the study hospitals dumped them with other wastes, adding to the hazards to public health and the environment. A common unsafe practice in most study hospitals was collecting and piling up medical waste uncovered in open areas within hospitals. In most cases, it would be a long period before this waste was transferred by city cleaning authorities to the final disposal destination outside hospitals, giving an opportunity for animals such as cats and even visitors to come into contact with the waste, as was the case in many hospitals. This was reported from a previous study in private health care centres in Palestine, which showed that almost all centres disposed of their medical waste in a random way [13].

\section{Waste-worker' injuries \& the administrations' responses}

High proportions of waste-workers in the hospitals in this study were injured by medical waste, highlighting the unfavourable situation in both government hospitals and private hospitals (28.7\% and $27.4 \%$ of workers respectively had been injured). These rates of injuries were unacceptable when compared with the rates recorded in developed countries which have been reported to range between $1.8 \%$ and $8 \%$ annually for health workers including cleaning staff [20]. On the other hand the rates were lower than the rate in Palestine (around $40 \%$ injured), which could be because of a high turnover of workers in the Yemeni hospitals, most of whom are temporary workers [13]. The injuries could be attributed to a lack of training in procedures of collecting and disposing of medical wastes and an absence of supervision. Similarly, a previous study concluded that operating without waste management authority and failing to give adequate warning signals were considered as unsafe acts, whereas developing pictorial training manuals was an essential part of the training component for raising awareness of risks [21].

\section{Study limitations}

A number of limitations to the study can be identified. There was anecdotal evidence that some departments of the hospitals or the private companies exaggerated their answers in order to improve their image. There were also large discrepancies between the reported and actual numbers of workers; for example, in the statements of the cleaners in 1 of the hospitals, we found that they contain 80 names while the actual number was only 20 workers. Moreover, the workers' supervisors may have adversely influenced workers' responses. Finally, the lack of a special medical waste department in many hospitals meant that waste management was not the responsibility of a specific person.

\section{Conclusions}

There was poor awareness about medical waste risks and safe handling procedures among hospital administrators, and most hospitals were not differentiating between domestic and medical waste. Budgets were not allocated for waste management purposes, which caused shortages in waste facilities handling equipment and supplies and absence of training programmes for staff, resulting in poor knowledge and practices of wasteworkers, a high rate of injuries and possible exposure of staff and visitors to hazardous waste.

\section{References}

1. Visvanathan C. Medical waste management issues in Asia. Paper presented at the Asia 3R Conference, Tokyo, Japan, 30 October-1 November, 2006.

2. Medical Waste Tracking Act of 1988. Section 11002. Listing of medical wastes. Washington DC, United States Environment Protection Agency, 1988.

3. US Congress. Office of Technology Assessment. Issues in medical waste management. Background paper, OTA-BP-O-49. Washington DC, US Government Printing Office, 1988.

4. Unsafe injection practices have serious, large-scale consequences. Studies point to injection-associated hepatitis C in Egypt. Press release. Geneva, World Health Organization, 2000 (WHO/1414).

5. Emmanuel J. Best environmental practices and alternative technologies for medical waste management. Paper presented at the Eighth International Waste Management Congress and Exhibition. Institute of Waste Management, Botswana, South Africa, 25-28 June, 2007.
6. Cheng YW et al. Medical waste production at hospitals and associated factors. Waste Management Journal, 2009, 29:440444.

7. Graikos A et al. Hazardous medical waste management at the regional level: the case of region of east Macedonia. Paper presented at the First International Conference on Hazardous Waste Management, Chania-Crete, Greece, 1-3 October, 2008.

8. Hagenmaier J et al. Catalytic effects of fly ash from waste incineration facilities on the formation and decomposition of polychlorinate dibenzo-p-dioxins and polychlorinated dibenzofurans. Environment, Science and Technology, 1987, 21:1080-1084.

9. Al-Khatib IA, Khatib RA. [Assessment of medical waste management in a Palestinian hospital]. Eastern Mediterranean Health Journal, 2006, 12:359-371 [in Arabic].

10. Abu-Awwad MQJ. Medical waste management in primary health care centers and private clinics: Jenin district [Masters the- 
sis]. Faculty of Graduate Studies, An-Najah National University, 2008:58.

11. A survey about wastes of medical facilities in Sana'a city. Sana'a, Yemen, Authority for the Protection of the Environment, 2006.

12. Prüss A, Giroult E, Rushbrook P. Safe management of wastes from healthcare activities. Geneva, World Health Organization, 1999.

13. Al-Khatib E. The development of the medical waste management sector in the private medical sector in Palestine. Eastern Mediterranean Health Journal, 2008, 14(5):1164-1172.

14. Mohandasundaram V. The environmental implications and economic issues in bio-medical waste management in urban Coimbatore, Tamilnadu, India. Paper presented at the Third International Conference on Environment and Health, Chennai, India, 15-17 December, 2003.

15. Moawad RK. National survey for the elimination of the solids hospital waste in Lebanon. Beirut, Pharmacy School, Lebanese University, 1997.
16. Basel Action Network (BAN). Eleven recommendations for improving medical waste management. Provided to the technical working group of the Basel convention, by the Basel Action Network (BAN), April 12-14, 1999. (http://www.ban.org/ library/11RECO 1.PDF, accessed 23 August 2011).

17. Mitchell J. Medical waste disposal. Rochester, New York, Rochester Committee for Scientific Information, 1999 (Bulletin No. 324).

18. Draft guidelines on BAT and BEP for medical waste incineration. Expert group on BAT and BEP. Geneva, United Nations Environment Programme, 2003 (UNEP/POPS/EGB.2/INF/9)

19. Rutala WA, Mayhall G. Medical waste. Infection Control and Hospital Epidemiology, 1992, 13:38-48.

20. Saia $M$ et al. Needlestick injuries: incidence and cost in the United States, United Kingdom, Germany, France, Italy, and Spain. Biomedicine International, 2010, 1:41-49.

21. Khan JA. Hospital waste management issues and steps taken by the Government of Pakistan. Islamabad, Pakistan, Ministry of Environment, 2006.

\section{Wastes from health-care activities}

Although treatment and disposal of health-care wastes aim at reducing risks, indirect health risks may occur through the release of toxic pollutants into the environment through treatment or disposal.

- Landfilling can potentially result in contamination of drinking water. Occupational risks may be associated with the operation of certain disposal facilities. Inadequate incineration, or incineration of materials unsuitable for incineration, can result in the release of pollutants into the air.

- Only modern incinerators are able to work at $800-1000{ }^{\circ} \mathrm{C}$, with special emission-cleaning equipment, can ensure that no dioxins and furans (or only insignificant amounts) are produced. Smaller devices built with local materials and capable of operating at these high temperatures are currently being field-tested and implemented in a number of countries.

- At present, there are practically no environmentally-friendly, low-cost options for safe disposal of infectious wastes. Incineration of wastes has been widely practised, but alternatives are becoming available, such as autoclaving, chemical treatment and microwaving, and may be preferable under certain circumstances.

The absence of waste management, lack of awareness about the health hazards, insufficient financial and human resources and poor control of waste disposal are the most common problems connected with health-care wastes. Improvements in health-care waste management rely on the following key elements:

- Building a comprehensive system, addressing responsibilities, resource allocation, handling and disposal;

- Raising awareness and training about risks related to health-care waste, and safe and sound practices;

- Selecting safe and environmentally-friendly management options, to protect people from hazards when collecting, handling, storing, transporting, treating or disposing of waste.

Government commitment and support are needed to reach an overall and long-term improvement of the situation, although immediate action can be taken locally.

Source: WHO Fact sheet, No. 253 